\title{
Karakteristik Reproduksi Sapi Aceh Betina di Kecamatan Pantan Cuaca Kabupaten Gayo Lues
}

\section{Characteristics Reproductive of Female Acehnese Cattle in Pantan Cuaca District, Gayo Lues Regency}

\author{
A. Makmur*, M. A. N. Abdullah, dan E. M. Sari \\ Program Studi Peternakan, Fakultas Pertanian, Universitas Syiah Kuala, Banda Aceh - Indonesia \\ *Corresponding E-mail: alimakmur379@yahoo.co.id \\ (Diterima: 14 Juli 2020; Disetujui: 30 September 2020)
}

\begin{abstract}
ABSTRAK
Penelitian ini bertujuan untuk mengidentifikasi dan menentukan kemampuan reproduksi sapi Aceh betina di Kecamatan Pantan Cuaca. Penelitian ini dilakukan meliputi 4 desa, yaitu desa Seneren, Remukut, Tetinggi, dan Suri Musara. Metode yang digunakan dalam adalah survei dengan menggunakan data dari 45 petani/peternak sebagai responden. Penentuan responden secara simple random sampling, dengan persyaratan minimal peternak memelihara dua ekor sapi Aceh. Data yang dikumpulkan meliputi karakteristik reproduksi, umur dewasa kelamin, service per conception $(\mathrm{S} / \mathrm{C})$, calving interval, dan umur penyapihan peded, faktor pendukung, dan data sekunder yang diperoleh dari instansi terkait. Data yang diperoleh di analisis statistik dengan menggunakan tabel frekuensi dan persentase. Hasil penelitian menunjukkan kelahiran pertama sapi aceh pada usia 2,6-3 tahun, dengan calving interval 14 bulan dan penyapihan peded rataan umur 6 bulan. Peternak jarang melakukan sanitasi kandang dan pengendalian penyakit, hanya beberapa peternak yang melakukan vaksinasi pada ternak.
\end{abstract}

Kata kunci: karakteristik, reproduksi, sapi Aceh

\section{ABSTRACT}

The purpose of this study was to identify and determine the reproductive ability of female Acehnese cattle. This research was conducted in the District of Pantan Cuaca, Gayo Lues Regency, which included four villages, namely Seneren, Remukut, Tetinggi, and Suri Musara villages. The method used in the survey is using data from 45 farmers/farmers as respondents-determination of respondents by simple random sampling, with minimum requirements for farmers to maintain two Aceh cows. Data collected included reproductive characteristics, sex adult age, service per conception $(S / C)$, calving interval and weaning age, supporting factors, and secondary data obtained from the relevant agencies. Data obtained in statistical analysis using frequency and percentage tables. The results showed the first birth of Acehnese cattle at the age of 2.6-3 years, with a 14-month calving interval and weaning peded at an average of 6 months. Breeders rarely carry out cage sanitation and disease control; only a few farmers do vaccinations on livestock.

Keywords: characteristics, reproduction, cow Aceh, Acehnese cattle

\section{PENDAHULUAN}

Permintaan daging sapi dari tahun ke tahun terjadi peningkatan seiring dengan bertambahnya penduduk, dimana pentingnya kesadaran mengkonsumsi daging untuk memenuhi kebutuhan protein. Kebutuhan daging sapi di Indonesia bersumber dari peternakan rakyat, industri peternakan rakyat (hasil penggemukan sapi ex-impor) dan daging impor (Guntoro, 2002). Untuk mencukupi kebutuhan daging, pemerintah berupaya akan meningkatkan efisiensi reproduksi dan mengatasi kasus ganggungan 
reproduksi. Sapi Aceh merupakan salah satu rumpun sapi Indonesia, mempunyai sebaran asli geografis di Provinsi Aceh dan Kabupaten Gayo Lues, umumnya diternakkan oleh masyarakat sebagai ternak potong, di samping itu juga digunakan sebagai ternak kerja, tabungan, budaya meugang dan adu sapi (Abdullah et al., 2007). Kondisi kebutuhan daging dalam negeri sampai saat ini masih mengalami kekurangan pasokan baik dalam bentuk ternak hidup berupa sapi bibit maupun sapi bakalan karena pertambahan populasi sapi potong tidak seimbang dengan kebutuhan nasional, sehingga terjadi impor sapi dan daging beku (Payne, 1997). Pada tahun 2015, jumlah populasi di Kabupaten Gayo Lues mengalami penurunan populasi yaitu 5.126 ekor, Kecamatan Pantan Cuaca merupakan salah satu kecamatan yang memiliki populasi sapi Aceh yang terbanyak yaitu 592 ekor, kemudian diikuti Kuta Panjang dan Blang Pengayon masing-masing 551 dan 491 ekor (BPS Gayo Lues, 2013). Sapi Aceh ditetapkan sebagai rumpun sapi asli Indonesia pada tahun 2011 oleh Menteri Pertanian RI melalui keputuan Menteri Pertanian Nomor 2907/ Kpts/OT.140/6/2011. Keunggulan sapi Aceh yang sangat menonjol terletak pada daya reproduksinya, karena sapi Aceh tergolong ternak masak dini dengan birahi postpartum sangat singkat. Abdullah (2007) menyatakan bahwa interval kelahiran sapi Aceh sangat pendek karena 3540 hari setelah beranak sapi aceh dapat birahi kembali dan dikawinkan berikutnya.

Tujuan pemeliharaan sapi Aceh bagi masyarakat di Kabupaten Gayo Lues adalah sebagai tenaga kerja, penghasil daging, pupuk dan tabungan keluarga. Mengingat pentingnya kedudukan ternak sapi Aceh ada kemungkinan pengembangan populasinya pada masa yang akan datang, dan hal ini dapat dipertimbangkan.Namun, untuk pelaksanaan peningkatan populasi sapi belum ada data-data dasar yang mendukung terutama belum ada data aspek reproduksinya dimana penelitian ini bertujuan mengetahui dan mengidentifikasi kemampuan reproduksi sapi Aceh betina di
Kecamatan Pantan Cuaca Kabupaten Gayo Lues.

\section{METODE}

Penelitian ini menggunakan metode survey, pemilihan lokasi dilakukan dengan metode Sampling dengan pertimbangan desa yang memiliki populasi ternak sapi aceh betina terbanyak pemeliaraan sapi semi intensif meliputi karakteristik reproduksi, umur dewasa kelamin, service per conception $(\mathrm{S} / \mathrm{C})$, calving interval dan umur penyapihan peded. Penentuan responden adalah dengan menggunakan metode Simple Random Sampling yaitu mengambil sampel dengan ketentuan minimal peternak memelihara dua ekor sapi betina. Ternak yang ditetapkan sebagai sampel sebanyak 146 ekor sapi betina telah beranak satu kali atau lebih. Responden ditetapkan sebanyak 45 orang peternak yang tersebar di empat desa yaitu Desa Seneren, Remukut, Tetinggi, dan Desa Suri Musara.

\section{Analisis Data}

Data telah dikumpulkan melalui observasi dan wawancara di lapangan. analisis statistik telah dilakukan dengan menggunakan tabel frekuensi dan persentase. Data yang telah terkumpul ditabulasikan kemudian ditetapkan nilai rataan dan standar deviasi menggunakan Software Microsoft Office Excell.

\section{HASIL DAN PEMBAHASAN}

\section{Tinjauan Umum}

Pantan Cuaca adalah Kecamatan yang terletak di Kabupaten Gayo Lues yang terbagi atas 9 Desa yaitu Desa Aih Selah, Atu Kapur, Cane Baru, Kenyaran, Seneren, Kuning Kurnia, Remukut, Tetinggi Dan Suri Musara. Sapi Aceh merupakan salah satu diantara jenis sapi yang dipelihara oleh masyarakat dengan pemeliharaan masih menerapkan secara tradisional. Tingkat perkembangan penduduk berdasarkan data tahun 2012, Kecamatan Pantan Cuaca memiliki jumlah penduduk sebanyak 5.214 jiwa. Salah 
Tabel 1. Tingkat pendidikan petani peternak di Kecamatan Pantan Cuaca Kabupaten Gayo Lues

\begin{tabular}{lcc}
\hline Tingkat Pendidikan & Jumlah Responden & Persentase (\%) \\
\hline Tidak Tamat SD & 5 & 11,11 \\
SD & 16 & 35,57 \\
SMP & 11 & 24,44 \\
SMA/SMEA/SMK & 11 & 24,44 \\
D2 & 1 & 2,22 \\
S1 & 1 & 2,22 \\
\hline Jumlah & 45 & 100,00 \\
\hline
\end{tabular}

satu mata pencarian masyarakat yaitu sub sektor peternakan dalam menjalankan usaha bertani dan kantoran, peran peternak banyak menggantungkan kehidupan mereka di sektor peternakan, seperti memelihara kerbau, sapi, ayam, kambing, itik, dan domba (BPS Kabupaten Gayo Lues, 2013).

Keadaan umum karateristik responden untuk distribusi tingkat pendidikan peternak menunjukkan bahwa umumnya peternak mempunyai pendidikan dasar (SD) yaitu sebesar 35,57\%, selanjutnya setingkat SMP dan SMA masing-masing sebesar $24,44 \%$. Ada juga peternak yang tidak pernah memperoleh pendidikan sekolah dasar (tidak mendapat pendidikan umum) yaitu $11,11 \%$ (Tabel 1). Hal ini menunjukkan bahwa petani peternak di Kecamatan Pantan Cuaca memiliki latar belakang pendidikan dasar (SD).

Pendidikan yang dimiliki seorang petani sangat mempengaruhi terhadap pendapatan yang diperoleh. Sebaliknya, tingkat pendidikan petani/peternak yang rendah membuat mereka sulit menyerap berbagai informasi, pengetahuan teknologi yang berhubungan dengan bidang peternakan.

Umumnya petani peternak di Kecamatan Pantan Cuaca berjenis kelamin laki-laki (95,5\%) dan sebagian kecil peternak berjenis kelamin perempuan yaitu $5 \%$. Tanggungan keluarga merupakan salah satu alasan utama bagi para ibu rumah tangga turut serta dalam membantu kepala keluarga serta memutuskan diri untuk bekerja memperoleh penghasilan.

Kisaran umur peternak mulai 20-
70 tahun. Petani peternak dalam kelompok umur 31-40 dan 41-50 tahun merupakan jumlah yang terbanyak dengan persentase masing-masing $35,37 \%$ dan $37,78 \%$. (Tabel 2). Kisaran umur 31-50 tahun merupakan tingkat usia yang produktif untuk bekerja, sehingga secara umum petani peternak masih berusia produktif dan dewasa. Usia peternak sangat mempengaruhi pengetahuan peternak terkait pemeliharaan yang benar, dimana teknik pemeliharaan ternak masih menggunakan secara tradisional karena tingkat pendidikannya peternak yang masih terbatas rataan tamat sekolah dasar 35,57\% (Tabel 1). Oleh karena itu, peran tenaga penyuluh peternakan sangat diperlukan untuk membina dan mengarahkan petani-peternak ke arah peternakan yang lebih baik (semi intensif dan intensif).

Jumlah keseluruhan sapi Aceh dari 45 responden adalah 277 ekor $(22,02 \%$ jantan dan $52,70 \%$ betina). Sebanyak $25,28 \%$ populasi sapi di Kecamatan Pantan Cuaca adalah sapi dara muda dan pedet (Tabel 5). Rasio sapi jantan dan betina dewasa adalah 1:3, sehingga perbandingan demikian tidak menjadi kendala dalam sistem perkawinan sapi secara alami, yaitu seekor sapi jantan dapat mengawini 3 ekor sapi betina produktif.

\section{Dewasa Kelamin}

Pemahaman responden menunjukkan bahwa, sebanyak $84,44 \%$ peternak mengerti ketika dewasa kelamin pada ternak sapi dan dapat menjelaskan saat ternak sapinya mengalami dewasa kelamin serta memperlihatkan tingkat laku sebagai ternak 
Tabel 2. Umur peternak sapi Aceh di Kecamatan Pantan Cuaca Kabupaten Gayo Lues

\begin{tabular}{lcc}
\hline Umur Responden & Jumlah & Persentase (\%) \\
\hline $20-30$ & 5 & 11,11 \\
$31-40$ & 16 & 35,37 \\
$41-50$ & 17 & 37,78 \\
$51-60$ & 4 & 8,89 \\
$61-70$ & 3 & 6,67 \\
\hline Total & 45 & 100,00 \\
\hline
\end{tabular}

yang sedang berahi. Hanya $15,56 \%$ peternak sapi Aceh di Kecamatan Pantan Cuaca yang tidak mengerti peristiwa dewasa kelamin pada ternak sapi (Tabel 3).

Peternak yang mengerti kapan saat dewasa kelamin sapinya, dapat menjelaskan tanda-tanda berahi yaitu: sapi gelisah, vulva bengkak dan berwarna merah jambu, ambing membesar, nafsu makan berkurang, suka menyendiri, vulva mengeluarkan lendir transparan, sapi yang berahi sering menunggagi sapi yang lain. Tanda-tanda tersebut pada sapi akan terulang lagi pada bulan berikutnya dalam suatu siklus berahi. Dewasa kelamin pada sapi Aceh betina di Kecamatan Pantan Cuaca terjadi pada umur 18 bulan. Peternak akan memisahkan sapi jantan dan betina sebelum mencapai dewasa kelamin untuk menghindari perkawinan pada usia muda. Umur ternak sapi dara pertama kali dikawinkan adalah pada 18-24 bulan (Handiwirawan dan Subandrio (2007). Pada umur demikian ternak sapi sudah mengalami dewasa tubuh (Pane, 1986).

\section{Service per Conception (S/C)}

Service per Conception (S/C) merupakan jumlah perkawinan sampai terjadinya kebundingan. Rata-rata Service per Conception (S/C) sapi Aceh yaitu sebesar 1,6. Informasi yang diperoleh tersebut bersumber dari S/C hasil perkawinan Inseminasi buatan (IB) diterapkan peternak sebesar 4,44\%. Sedangkan S/C hasil perkawinan secara alami tidak dapat diketahui karena sistem pemeliharaan sapi dengan sistem dilepas, sehingga kapan sapi kawin akan sulit diketahui dengan tepat. Nilai S/C sebesar 1,6 merupakan angka S/C yang baik. nilai S/C yang normal pada ternak sapi berkisar 1,6 sampai 2,0 (Affandi et al., 2003).

Apabila dibandingkan dengan angka S/C sapi lain, sapi PO dan Peranakan Limousine seperti yang dilaporkan Nuryadi dan Wahjuningsih (2011), masing-masing memiliki angka S/C 1,28 dan 1,34, maka kedua angka ini lebih rendah dibandingkan dengan S/C pada sapi Aceh. Sapi Madura hasil penelitian Harmadji (1992) yang disitasi Wijono dan Setiadi (2004), sapi Madura mempunyai $\mathrm{S} / \mathrm{C}$ yang lebih besar yaitu 1,72,0. Sapi Bali memiliki angka $\mathrm{S} / \mathrm{C} 1,41$ (Panjaitan et al., 2003), yang menunjukkan angka yang lebih rendah dibandingkan sapi Aceh. Menurut Nuryadi dan Wahjuningsih (2011), apabila S/C rendah, maka nilai kesuburan sapi betina semakin tinggi dan apabila nilai S/C tinggi, maka semakin rendah tingkat kesuburannya.

\section{Calving Interval}

Calving Interval ditentukan oleh lama kebuntingan dan lama waktu penyapihan pedet (Hunter, 1991). Rataan jarak beranak (calving interval) sapi Aceh menunjukkan sebesar 13,5 bulan dengan kisaran 12-15 bulan. Secara umum, peternak yang memelihara sapi Aceh betina yang mempunyai jarak beranak 14 bulan yaitu sebesar 40\% (Tabel 4).

Puslitbangnak (2010) telah merekomendasikan bahwa, untuk suatu usaha breeding sapi potong yang efisien, jarak beranak (calving interval) pada sapi ialah di bawah 14 bulan. Menurut Salisbury 
Tabel 3. Tingkat pengetahuan peternak terhadap dewasa kelamin pada sapi Aceh di Kecamatan Pantan Cuaca

\begin{tabular}{lcc}
\hline Tanda Sapi Pertama Kali Berahi & Jumlah & Persentase (\%) \\
\hline Tidak Mengerti & 7 & 15,56 \\
Mengerti & 38 & 84,44 \\
\hline Total & 45 & 100,00 \\
\hline
\end{tabular}

Tabel 4. Calving Interval (CI) sapi Aceh di Kecamatan Pantan Cuaca Kabupaten Gayo Lues

\begin{tabular}{cccc}
\hline No. & Calving Interval (bulan) & Jumlah Responden & Persentase (\%) \\
\hline 1 & 12,0 & 3 & 6,67 \\
2 & 13,0 & 15 & 33,33 \\
3 & 14,0 & 18 & 40,00 \\
4 & 15,0 & 9 & 20,00 \\
\hline Rataan & 13,5 & 45 & 100,00 \\
\hline
\end{tabular}

dan Demark (1985), jarak beranak pertama dengan selanjutnya berkisar pada $366-480$ hari atau 12,2-16 bulan. Sebenarnya jarak beranak yang ideal adalah 12 bulan sehingga diperoleh hasil pedet pertahun.

Menurut Hardjosubroto et al. (1993), jarak beranak sapi Madura yaitu 14,9 bulan. Nuryadi dan Wahjuningsih, (2011) menambahkan apabila dibandingkan dengan sapi PO dan Peranakan Limousin rata-rata CI sapi (433 hari) lebih panjang dibandingkan dengan sapi Peranakan Ongole (414 hari). Nilai CI pada sapi PO, Peranakan Limousine dan sapi Aceh (13,5 bulan). Hal ini bisa dikatakan belum ideal, menurut pendapat Hadi dan Ilham (2004) bahwa, jarak waktu beranak (CI) yang ideal yaitu 12 bulan, dimana 9 bulan bunting dan 3 bulan menyusui. Kembali ditambahkan oleh Ball and Peters (2004) bahwa, apabila efisiensi reproduksi dikatakan baik dari seekor induk sapi dapat menghasilkan satu pedet dalam satu tahun.

Penampilan reproduksi jarak beranak (Calving Interval) sapi Aceh di Kecamatan Pantan Cuaca berada dalam kondisi yang kurang baik karena umur jarak beranak mencapai di atas12 bulan. Umumnya (sebanyak 40\%) responden yang memelihara sapi Aceh telah mengamati ternak sapinya mempunyai jarak beranak 14 bulan bahkan ada responden sebanyak 20\% yang melaporkan sapinya mempunyai jarak beranak mencapai 15 bulan. Menurut Guntoro (1995), lama umur jarak beranak sapi dapat dipengaruhi oleh manajemen yang tidak terkontrol dan kurang baik. Untuk memperpendek jarak beranak sebaiknya tidak harus menunggu penyapihan pedet, yaitu sekitar 2 bulan (60 hari) atau bisa dilakukan setelah berlangsung siklus berahi.

\section{Penyapihan Pedet}

Penyapihan pedet merupakan proses pemisahan antara induk dan pedet dengan tujuan untuk membatasi hingga menghentikan proses menyusui. Penyapihan pedet menunjukkan bervariasi antara 5 hingga 7 bulan (Tabel 5). Penyapihan ini sesuai dengan pendapat Reksohadiprodjo (1995) bahwa, penyapihan umur pada pedet sapi yang ideal disapih pada umur 6-7 bulan.

Rataan penyapihan pedet pada sapi Aceh adalah pada umur 6 bulan. Apabila dibandingkan dengan sapi lain, sapi Madura menurut Harmadji (1992) yang disitasi Wijono dan Setiadi (2004), penyapihan pedet sapi Madura umumnya dilakukan pada umur 5 bulan. Pada sapi Bali, umumnya pedet disapih pada umur 7 bulan (Bamualim dan Wirdahayati, 2002). Namun pada penyapihan dini, pedet dapat disapih pada umur 3-6 bulan. Penyapihan yang lebih cepat merupakan 
JPI Vol. 22 (3): 306-312

Tabel 5. Umur penyapihan pedet sapi Aceh di Kecamatan Pantan Cuaca Kabupaten Gayo Lues

\begin{tabular}{lcc}
\hline Umur penyapihan (bulan) & Jumlah Responden & Persentase (\%) \\
\hline 5 & 10 & 22,22 \\
6 & 21 & 46,67 \\
7 & 14 & 31,11 \\
\hline
\end{tabular}

strategi untuk meningkatkan kemampuan hidup pedet dan mengurangi tingkat kematiannya (Pamungkas et al., 2007). Wirdahayati (2000) melaporkan di Timor Timur bahwa penyapihan dini sapi Bali dapat dilakukan asalkan diiringi dengan pemberian hijauan berkualitas bagus ditambah susu pengganti, khususnya pada umur penyapihan 3 bulan. Pemberian nutrisi yang bagus diiringi dengan strategi manajemen dapat meningkatkan produktivitas sapi Bali.

\section{KESIMPULAN}

Karakteristik sapi aceh betina di Kecamatan Pantan Cuaca Kabupaten Gayo Lues sudah cukup baik sesuai standar yang diharapakan dimana responden mengerti pada umur berapa dewasa kelamin ternak sapi aceh betina 84,44 \%. Service per Conception (S/C) sapi Aceh yaitu sebesar 1,6. Informasi tersebut yang diperoleh $\mathrm{S} / \mathrm{C}$ hasil perkawinan secara Inseminasi Buatan (IB) yang diterapkan peternak sebagai responden sebesar 4,44\%. Rataan calving interval adalah 13,5 bulan dan penyapihan pedet berumur 6 bulan. Disarankan agar pemerintah daerah setempat memperhatikan petani peternak sapi mengintensifkan penyuluhan untuk mengembangkan peternaks sapi lebih baik dan maju dimasa yang akan datang.

\section{DAFTAR PUSTAKA}

Abdullah, M. A. N., R. R. Nor. H. Martojo., D. D Solihin, dan E. Handiwirawan. 2007. Keragaman fenotipik Sapi Aceh di Nanggroe Aceh Darussalam. J. Indon Tropic Agriculture.Aceh.

Affandi., L. P. Situmorang., P. W. Prihandini.,
D. B. Wijono, dan Rasyid. 2003. Performans Reproduksi dan Pengelolaan Sapi Potong Induk Pada Kondisi Peternakan Rakyat. Puslitbang Peternakan.

Ball, P. J. H. and Peters, A. R. 2004. Reproduction in Cattle Third Edition. Blackwell Publishing. Victoria, Australia.

Bamualim dan Wirdahayati. 2002. Anatomi dan Histologi Alat Reproduksi Ruminansia. Bandung.

BPS Kabupaten Gayo Lues. 2012. Gayo Lues Dalam Angka. Biro Statistik GayoLues, Blangkejeren.

BPS Kabupaten Gayo Lues. 2013 Laporan Hasil Sensus Pertanian Kabupaten Gayo Lues, Blangkejeren.

Guntoro, S. 2002. Membudidayakan Sapi Bali. Penerbit Kanisius, Yogyakarta.

Hadi, U. dan Ilham, N. 2002. Problem dan Prospek Pengembangan Usaha Pembibitan Sapi Potong di Indonesia. Pusat Penelitian dan Pengembangan Sosial Ekonomi Pertanian. Bogor.

Handiwirawan E. dan Subandriyo. 2007. Potensi dan Keragaman Sumberdaya Genetik Sapi Bali. http://peternakan. litbang.deptan.go.id/download/sapi/ sapo 04-9.

Hardjosubroto, W., Endang. B. dan SidqiZaud. 1993. Kapasitas suplai sapi Madura dari pulau Madura. Pros. Pertemuan Ilmiah Hasil Penelitian dan Pengembangan Sapi Madura. Sub Balitnak Grati. Sumenep. hlm. 198210.

Hunter, F. H. R. 1991. Fisiologi dan Teknologi Reproduksi Hewan Betina DomestikI. 
Institut Teknologi Bandung Press. Bandung.

Nuryadi dan S. Wahjuningsih. 2011. Penampilan reproduksi sapi Peranakan Ongole dan Peranakan Limousin di Kabupaten Malang. J. Ternak Tropika. 12(1): 76-81.

Pamungkas, D., Y. N. Anggraeny., A. Priyanti, dan N. H. Krishna. 2007. Pola pertumbuhan pedet sapi Bali lepas sapih yang diberi hijauan pakan berbeda. Seminar Nasional Teknologi Peternakan dan Veteriner. Loka Penelitian Sapi Potong, Grati, Pasuruan.

Pane, I. 1986. Pemuliabiakan Ternak Sapi I. PT. Gramedia: Jakarta.

Panjaitan, T. S., W. R. Sasongko., A. Muzani, Mashur, dan W.Arief. 2003. Manajemen Terpadu Pemeliharaan Sapi Bali. Badan Penelitian dan Pengembangna Pertanian.Balai Pengkajian Teknologi Pertanian. Nusa Tenggara Barat.

Puslitbang Peternakan. 2010. Rekomendasi Teknologi Peternakan dan Veteriner
Mendukung Program Swasembada Daging Sapi (PSDS) Tahun 2014.

Payne, W. J. A. 1997. Tropical Cattle; Origin, Breeds, and Breeding Policies. Blackwell Sciences.

Salisbury, G. W. dan N. L. VanDemark. 1985. Fisiologi Reproduksi dan Inseminasi Buatan pada Sapi. Gadjah Mada University Press. Yogyakarta.

Reksohadiprodjo, S. 1995. Pengantar Ilmu Peternakan Tropik. BPFE. Yogyakarta.

Wijono, D. B. dan B. Setiadi. 2004. Potensi dan Keragaman SumberDaya Genetik Sapi Madura. Lokakarya Nasional Sapi Potong. Loka Penelitian Sapi Potong, Grati.

Wirdahayati, R. B. 2000. Parameter fenotipik dan genetik sifat produksi dan reproduksisapi Bali pada Proyek Pembibitan dan Pengembangansapi Bali (P3Bali) di Bali. Thesis Fakultas Pasca Sarjana, Institut Pertanian Bogor, Bogor. 